\title{
Impact of Employee Training on Organizational Performance - Case Study of Drilling Companies in Geita, Shinyanga and Mara Regions in Tanzania
}

\author{
Dr. Janes O. Samwel, PhD* \\ East Africa Regional Human Resource Manager, Ausdrill East Africa, P.O Box 1917, Mwanza, Tanzania \\ *Corresponding Author: Dr. Janes O. Samwel, PhD, East Africa Regional Human Resource Manager, \\ Ausdrill East Africa, P.O Box 1917, Mwanza, Tanzania
}

\begin{abstract}
Effective performance of any organization deeply depends on the performance of its employees; therefore employee training is something unavoidable in the organization and should not be overlooked or undermined. Drilling companies need well trained, competent and experienced employees to meet their goals and objectives. The purpose of the study was to analyse the impact of employee training on the performance of drilling companies in Geita, Shinyanga and Mara Regions in Tanzania and to provide concrete evidence on the contribution of employee training on performance of drilling companies. The study comprised a sample size of 219 respondents selected using purposive and simple random sampling techniques. Data collection was done through the questionnaire administered to the respondents. Data was analysed using descriptive statistics and results presented using tables. The study results found that employee training has a significant effect on the performance of drilling companies. However, the study results found lack effective training and development policies in drilling companies. The study recommended that there is a need for drilling companies to develop proper and effective training and development policies which will guide their training procedures also help in the implementation of training strategies.
\end{abstract}

Keywords: Employee training, Organizational performance and Drilling Companies.

\section{INTRODUCTION}

\subsection{Background of the Study}

Employee training is one of the vital tools that help to enhance effective organizational performance and at the same time helps to promote the stability index of the organization. It is very important for the organization to exert extra efforts and invest much in employee training if it wants to achieve its objectives in the most economical way.Shaw (2011) defined training as a process that provides employees with skills,information and understanding of the organization and its goals. Training is a systematic process, which helps people to learn how to be more effective at work by modifying knowledge, skills or attitudes through learning experience to achieve effective performance (Buckley \& Caple, 2000).Training is very important in achieving the objectives of the organization by continuing to view the interest of employees and organization (Stone, 2002).Improved capabilities, knowledge and skills of the talented workforce have been proved to be the main source of competitiveadvantage in a global market (McKinsey, 2006). When the organization is unable to deliver effective training to its employees it is not only the employees who suffer, the impact can be felt by the organization itself.If someone is not delivering the training in an impressive style and he is not capturing the attention of the audience it means he is wasting the time(Griffin et al, 2000). Trainingprimarily focuses on teaching the organizational members how to perform their current jobs and at the same time help them to acquire the knowledge and skills they need to be effective performers (Jones, George \& Hill, 2000).

Effective training programs help in building a supportive and conducive learning environment to the workforce and at the same time help them to deal effectively with foreseeable challenges easily and in time (Tai, 2006). In order for managers to meet the objectives of their employees' training, they must understand the benefits of the training to the organization and to the employees, identify the training needs of the employee and finally have effective training design that lies in the heart of organizational 
objectives. The need and objectives of the training program should be identified before offering training to employees(Obisi, 2001).Bad training design is nothing but the loss of time and money (Tsaur \& Lin, 2004). It is very important for the organization to design the employee training very carefully (Armstrong, 2000).Organizations which develop effective training design that based on the needs of employeesand the organization always get good results (Partlow, 1996). Managers should do everything possible within their control to develop the capabilities of employees (Brinkerhoff, 2006). Effective training programs help employees to advance themselves with new technologyand at the same time gaining full command of the skills and competencies necessary to carry out a specific task and to avoid mistakes on the job (Gunter Walden, 2011).

Employee training can be on the job training or off the job training, this depends on the decision of the organization itself on which method meet its training needs and objective on which method meet its training needs and objective, some organizations prefer on the job training while others prefer off the job training.It is better for the organizations to give their employees on the job training because it is cost effective and time-saving (Ruth \& Doug 2004). On the job training enable employees to learn in a practical way (Tom Baum et al., 2007).On-the-job training is useful in developing and practising specific managerial, leadership, technical, manual and administrative skills needed by the organization to improve competitiveness (Armstrong, 1998).

\subsection{Statement of the Problem}

Achieving employee training goals and objectives is a big challenge for many organizations including drilling companies. The quality of training has been a subject for discussion for many drilling companies. Today some drilling companies suffer in terms of performance because of the lack of effective employee training. Performance is the key element to achieve the goals of the organization (Mwita, 2000).

\section{LITERATURE REVIEW}

\subsection{Employee Training as a Source of Competency}

Training enables employees to be competent and more effective in their work. According to Wright and Geroy (2001), effective training programmes change the competency level of an employee positively. Mathis and Jackson (2008) argued that training and development are also a means for employers to address the employees' needs. Robert (2006) stated that effective training programmes help employees to acquire new technology that helps them to perform their job and at the same time gaining full command on the competencies and skills required to perform that particular job with fewer errors and mistakes. Relatively, Valle et al, (2000) supported that effective training helps the organization to build and maintain employee's capabilities. Jie and Roger (2005) narrated that raining help the organization to enhance its employee's abilities and competencies that are needed in the workplace.

\subsection{Employee Training as a Motivation Factor}

One of the most important factors that motivate the employee is training. Swart et al. (2005) affirmed that employees normally perform better when they are given adequate and appropriate training programs that motivate them and lead them to fulfil their needs. Anonymous (1998) emphasized that training is essential not only to increase productivity but also to motivate and inspire workers by letting them know the importance of their jobs and giving them all the information they need to perform those jobs. Myles (2000) confirmed that a company that seeks to train and develop its employees and reward them well for their performance makes them motivated by improving their performance and loyalty to the company.

\subsection{Employee Training as a Source of Productivity}

In recent years training has been one of the crucial element that plays a vital role in increasing organizational productivity. Konings and Vanormelingen, (2009) proposed that training is a fundamental and effectual instrument in the successful accomplishment of the firm's goals and objectives, resulting in higher productivity. Bartel (2004) opined that effective training programmes and high productivity on the part of the employee are positively correlated. 


\subsection{Employee Training as a Source of Commitment}

Ahmad and Bakar (2003) pointed out that if training is achieved on both individual and organizational level, then it brings a high level of commitment on the part of employees Serkan and Emir (2014) highlighted that training should be planned in such a way that it results in the commitment of the organization. Mthokozisi and Clifford (2015) affirmed that commitment of employees is as a result of some human resource practices such as career development and training opportunities. Eisenberger et al.(1986) stated that workers feel more committed to the firm when they feel the organizational commitment towards them and thus show higher performance. Bartlett (2001) opined that companies can gain a competitive advantage over their opponents by investing in training because training can enhance employee commitment.

\subsection{Employee Training Improved Performance}

According to Harrison (2000), learning through training is said to be a key factor in increasing employees performance, achieving corporate goals and also influencing the performance of the organization. Swart et al. (2005) suggested that performance gap of employees can be bridged by implementing a relevant training method in order to develop particular skills and abilities of the workers thereby enhancing the performance of employees.Chiaburu and Tekleab (2005) commented that training is a planned intervention aiming at enhancing the elements of individual job performance. Nguku (2006) contended that that employee training assists employees in acquiring better skills, knowledge and attitudes towards their better performance.

\subsection{Employee Training Increase Job Satisfaction}

Amisano (2010) stressed that employee performance depends on many factors like job satisfaction, knowledge and management. Champathes (2006) advocated that well trained and developed employees are satisfied with their job hence leads to an increase of the organizational productivity and profitability. Rowden (2002) emphasized that training may also be an effective tool for improving one's job satisfaction. Tsai et al (2007) affirmed that employees who learn as a result of training program show a greater level of job satisfaction along with superior performance.

\subsection{Employee Training as a Source of Retention}

Noe (2001) narrated that organizations that embrace training and development practices are able to retain customers, suppliers, employees, stakeholders and shareholders in the long-run. Kauffman (2010) argued that when it comes to improving employee retention. it is imperative to use grass-roots employee involvement program like training in the firm's business.

\section{RESEARCH METHODOLOGY}

The study adopted survey design. The study used purposive and simple random sampling techniques to select a sample size of 219 respondents from the target population of 484 employees from three drilling companies in Geita, Shinyanga and Mara regions. The study used the questionnaire to collect data. Data analysis was done using descriptive statistics such as frequencies and percentages and results were presented using tables.

\section{ANALYSIS AND FINDINGS}

Table1. On the job Training methods/techniques

\begin{tabular}{|l|l|l|l|}
\hline & \multicolumn{1}{|c|}{ Frequency } & \multicolumn{1}{c|}{ Percent } & \multicolumn{1}{c|}{ Cumulative Percent } \\
\hline Orientation & 96 & 43.8 & 43.8 \\
\hline Job Rotation & 71 & 32.4 & 76.3 \\
\hline Coaching & 32 & 14.6 & 90.9 \\
\hline Project Assignments & 20 & 9.1 & 100.0 \\
\hline Total & 219 & 100.0 & \\
\hline
\end{tabular}

The study sought to know on the job training methods/techniques used by drilling companies to train their employees. The findings in table 4.1 show that $43.8 \%$ of the drilling companies use orientation, $32.4 \%$ use job rotation, $14.6 \%$ use coaching while $9.1 \%$ assign their employees to project assignments to acquire some skills and knowledge as their own job training methods/techniques. 
Impact of Employee Training on Organizational Performance - Case Study of Drilling Companies in Geita, Shinyanga and Mara Regions in Tanzania.

Table2. Off the job Training methods/techniques

\begin{tabular}{|l|l|l|l|}
\hline & \multicolumn{1}{|c|}{ Frequency } & Percent & \multicolumn{1}{c|}{ Cumulative Percent } \\
\hline Conference and workshops & 126 & 57.5 & 57.5 \\
\hline Seminars & 69 & 31.5 & 89.0 \\
\hline Training Institutions & 24 & 11.0 & 100.0 \\
\hline Total & 219 & 100.0 & \\
\hline
\end{tabular}

The study also sought to know off the job training methods/techniques used by drilling companies to train their employees. The findings in table 4.2reveal that $57.5 \%$ of the drilling companies use conference and workshops, $31.5 \%$ use seminars, while $24 \%$ use training institutions as their off job training methods/techniques.

Table3. Types of employee training offered from 2009 to 2016

\begin{tabular}{|l|l|l|l|}
\hline & \multicolumn{1}{|c|}{ Frequency } & \multicolumn{1}{c|}{ Percent } & \multicolumn{1}{c|}{ Cumulative Percent } \\
\hline Safety & 114 & 52.1 & 52.1 \\
\hline General Drilling training & 66 & 30.1 & 82.2 \\
\hline Leadership and supervision & 25 & 11.4 & 93.6 \\
\hline Labour law & 14 & 6.4 & 100.0 \\
\hline Total & 219 & 100.0 & \\
\hline
\end{tabular}

The study targeted to know the types of the training that have been offered to employees since 2009 to 2016. The findings in table 4.3 demonstrate that $52.1 \%$ of the drilling companies have offered safety training, $30.1 \%$ have offered general drilling training, $11.4 \%$ have offered leadership and supervision skills development and only $6.4 \%$ of the drilling companies have offered labour law training. This implies that drilling companies are focusing much on what I call safety and technical training while less emphasis is put on management training such as labour laws.

Table4. Benefits of employee training to drilling companies

\begin{tabular}{|l|l|l|l|}
\hline & Frequency & Percent & Cumulative Percent \\
\hline Have competent and self-motivated staff/employees & 56 & 25.6 & 25.6 \\
\hline Have positive commitment to the company & 52 & 23.7 & 49.3 \\
\hline Quality service and product & 44 & 20.1 & 69.4 \\
\hline Employee fill part of the company and stay long & 32 & 14.6 & 84.0 \\
\hline $\begin{array}{l}\text { Trained staff enables the company to maintain its competitive } \\
\text { advantage }\end{array}$ & 35 & 16.0 & 100.0 \\
\hline Total & 219 & 100.0 & \\
\hline
\end{tabular}

The study wanted to know the benefits of employee training to drilling companies, on this, the respondents were asked to mention any benefit they believe that comes to the company as a result of employee training. The findings in table 4.4 depict that $25.6 \%$ of the respondents said that through employee training the company gets competent and self-motivated staff, $23.7 \%$ narrated that training enables employees to have a positive commitment to the company, $20.1 \%$ affirmed that training enables employees to provide quality service and product to the customers/clients. Moreover, the findings highlight that $14.6 \%$ of the respondents advocated that training enables employees to feel that they are part of the company and this makes them stay longer with the company while $16 \%$ postulated that employee training helps the companies to maintain its competitive advantage. These findings imply that drilling companies know very well the benefits of employee training on their performance.

\section{CONCLUSION}

Employee training plays a fundamental role on the performance of drilling companies. The study highlighted that drilling companies know the benefits of employee training on their performance. Despite knowing the importance of employee training, drilling companies still lack effective employee training and development policy also management training such as leadership, supervision and labour law seems not to be their priorities. The study concluded that drilling company should see the necessity of having effective employee training and development policy and at the same time consider management training as one of the important employee training. 


\section{REFERENCES}

[1] Ahmad, Z.K., \& Bakar, R.A. (2003). The association between training and organisational commitment among the white-collar workers in Malaysia.International Journal of Training and Development,7(3), 166-185.

[2] Anonymous. (1998, Sept/Oct). What nonprofits need to know about technology. Nonprofit World, 16, 38.

[3] Armstrong, M. (1998); Human Resource Management: Strategy and Action, Irwin, Boston.

[4] Armstrong, M. (2000). “Understanding training”. Human Resource Management Practice. 8th Edition. Kogan page limited, London. pp:543.

[5] Bartlett, K. R. (2001). The relationship between training and organizational commitment: A study in the health care field. Human Resource Development Quarterly, 12(4), 335-352.

[6] Bartel, A. (2004). "Human Resource Management and Organizational Performance: Evidence from Retail Banking." Industrial and Labor Relations Review, 57(2),181- 203.

[7] Brinkerhoff, R. O. (2006). Increasing Impacts of Training Investments: An Evaluation Strategy for BuildingOrganizational Learning Capability, Industrial and Commercial Banking. Emerald Group of Publishers, 38(6),302-307.

[8] Buckley, R. and Caple, J. (2000), The Theory and Practice of Training,(4th ed.). Kogan Page Ltd.

[9] Champathe, M.R. (2006). Coaching for performance improvement: The coach model. Development and Learning in Organziazations, 20(2),1-17.

[10] Chiaburu, D.S., \& Amanuel, G.T. (2005)."Individual and contextual influences on multiple dimensions of training effectiveness", Journal of European Industrial Training, 29(8) 604-626.

[11] Chris, A. (2010). eHow contributer "Relationship between traning and employee performance"http://hrcouncil. ca/hr-toolkit/learning-implementing.cfm.

[12] Eisenberger, R., Huntington, R., Hutchison, S., \& Sowa, D. (1986). Perceived organizational support. Journal of Applied Psychology, 71 (3), 500-507.

[13] Griffin, M.A., \& Andrew, N. (2000). "Perceptions of Safety at Work: A Framework for Linking Safety Climate to Safety Performance, Knowledge, and Motivation". Journal of Occupational Health Psychology, 5(3), 347-358.

[14] Gunter Walden, K. T.(2011). Apprenticeship Training in Germanystill a future-oriented model for recruiting skilled workers? Journal of Vocational Education and Training, 305- 322.

[15] Harrison, R. (2000). Employee Development, Beekman Publishing. Silver Lakes, Pretoria.

[16] Jie, S. (2005). "International Training and Management Development, Theory and Reality". Journal of Management Development, 24(7), 656-666.

[17] John, I.M. (2000). "Performance management model: A systems-based approach to public service quality", International Journal of Public Sector Management, 13(1), 19-37.

[18] Jones, G.R., George, J.M., \& Hill, C.W.L. (2000) Contemporary Management. New York, Irwin andMcGraw Hills Companies,Inc.

[19] Kauffman C 2010. Employee involvement: A new blueprint for success. Journal of Accountancy, 209 (5): 46-49.

[20] Konings, J., \& Vanormelingen, S. (2009). The Impact of Training on Productivity and Wages: Firm Level Evidence, Discussion Paper No. 244, Available at SSRN

[21] Mathis, R.L., \& Jackson, J.H. (2008). Human Resource Management. (12th ed.). Cengage Learning.

[22] Mthokozisi, M.,\& Clifford, K. H. (2015). Training and development as a tool for improving basic service delivery; the case of a selected municipality, Journal of Economics, Finance and Administrative Science, 133- 136

[23] McKinsey Quartely .(2006). Organizing for successful change management. An executive take on the top business trends. A McKinsey Quarterly Global Survey of business executives.

[24] Myles Dowrey, (2000). Effective coaching: Lessons from the coach.

[25] Nguku, J.K.M (2006) A survey of staff training and development practices in state corporations In Kenya .Unpublished MBA project; University of Nairobi.

[26] Noe,Raymond, (2001) Human Resource Management (2nd ed.).Prentice Hall.

[27] Obisi, C. (2001). Employee development, Issues and dimensions, Unical Journal of public Administrator, 1(51), 15-34.

[28] Partlow, C.G. (1996). "Human-resources practices of TQM hotels", Cornell Hotel \&RestaurantAdministration Quarterly, 37(5),67-77. 
[29] Robert B. O. (2006). "Increasing Impact of Training Investments: an Evaluation Strategy for Building Organizational Learning Capability”, Industrial and Commercial Training, 38(6), 302-307.

[30] Rowden, R.W. (2002), "The relationship between workplace learning and job satisfaction in small and mid-sized businesses", Human Resource Development Quarterly, Vol.13(4),407-26.

[31] Ruth T., \& Doug, D. (2004). "Aspects of training and remuneration in the accommodation industry". Journal of European Industrial Training, 28(6),1-2.

[32] Serkan, B., \& Emir, C. (2014). Impact of Training and Development on Employees Performance in Bosnia And Herzegovina. European Researcher, 89(12) 2125-2132,

[33] Shaw, (2011). Turnover rates and organizational performance: Review, critique, and research agenda. Organizational Psychology Review, 1(3), 187-213.

[34] Stone, R.J. (2002). Human Resource Management (2nd Ed.). John Wiley \& Sons.

[35] Swart, J., Mann, C., Brown, S.,\& Price, A. (2005).Human Resource Development: Strategy and Tactics. Elsevier Butterworth- Heinemann Publications.

[36] Tai, W.T. (2006). Effects of training framing general self-efficacy and training motivation on trainees' training effectiveness. Personnel Review, 35(1), 51-65.

[37] Tom, B., \& Frances, D. (2007). "Skills and training in the hotel sector: The Case of front office employment in Northern Ireland". International Journal of Hospitality Management 7(3-4),269-280.

[38] Tsai, P., Yen, C.Y., Huang, L., \& Huang, I. (2007), “A study on motivating employee's learning commitment in the post-downsizing era: job satisfaction perspective", Journal of World Business, 42(2), 157-69.

[39] Tsaur, S.H., Lin, Y.C.(2004). "Promoting service quality in tourist hotels: the role of HRM practices and service behavior", Tourism Management, 25(5), 471-481.

[40] Valle, R., Mart1'n, F., Romero, P.M. and Dolan, S. (2000), "Business strategy, work processes and human resource training: are they congruent?",Journal of Organizational Behavior, 21(283-97.

[41] Wright, P.,\& Geroy, D.G. (2001). Changing the mindset: the training myth and the need for word-class performance,International Journal of Human Resource Management, 12 (4),586-596.

\section{AUTHORS' BIOGRAPHY}

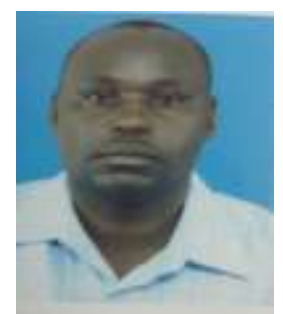

Dr. Janes O. Samwel, PhD is a Decisive, enthusiastic, Self-Disciplined, selfmotivated and result driven HR professional with 13 years of experience in Human Resource management and Administration. Resourceful and effective human resource professional with proven proficiency in all human resource and administration aspects with knowledge of Human Capital Management, staffing, performance management, employee records management, employee training and development, employee relations, human resource strategic planning, compensation/reward management, Human resource information systems, Discipline management, Strategic Human Resource Management, operations management, social programme development, project management, safety management, project reports, team management and leadership, business development, coaching, Talent Acquisition and management, Business Planning, Marketing management, International Human Resource Management, sales management, contract negotiation, community and public Relations, succession planning, Cooperate affairs management, E-Recruitment and E-Learning. Competencies in conflict resolution and grievance management, Discipline management, good in designing training programmes and maintaining team work, equipped with analytical and strong management and leadership skills, expertise in human resource policies development and implementation, good knowledge of employment law and practices as well as Tanzania Labour law with good records of handling and winning labour cases, proficient in managing HR budget and good in maintaining relationship with organization stakeholders.

Citation: Dr. Janes O. Samwel, PhD. "Impact of Employee Training on Organizational Performance - Case Study of Drilling Companies in Geita, Shinyanga and Mara Regions in Tanzania." International Journal of Managerial Studies and Research (IJMSR), vol 6, no. 1, 2018, pp. 36-41. doi:http://dx.doi.org/10.20431/ 2349-0349.0601005.

Copyright: () 2018 Authors. This is an open-access article distributed under the terms of the Creative Commons Attribution License, which permits unrestricted use, distribution, and reproduction in any medium, provided the original author and source are credited. 